\title{
A BABASÉMA OPTIMUMÁNAK VIZSGÁLATA ÉLETTELEN TÁRGYAKON
}

\author{
KISS-LEIZER MÁRTON \\ PPKE BTK Pszichológia BA \\ E-mail: leizermarton@gmail.com
}

Beérkezett: 2015. április 15. - Elfogadva: 2017. február 9.

\begin{abstract}
Konrad Lorenz etológus tárgyalta elöször, hogy bizonyos fizikai jellemzók, mint a nagy fej, a gömbölyded arc, a magas homlok, a kis orr és száj, valamint a nagy szem - amelyek a kisbabák arcának jellemzôi vonzónak, aranyosnak hatnak, és gondozóviselkedésre irányuló motivációt aktiválnak a felnôttekben. Az általa megalkotott babaséma (,Kinderschema”) fogalom azóta már széles körben bebizonyította a hatását a humán percepcióra, hiszen többek között orientálja a figyelmet, lokálissá teszi az észlelést, preferenciát vált $k i$, sốt akár élettelen tárgyakra vonatkoztatva is megváltoztatja itéletünket. A kutatások fókuszpontján azonban mindeddig kivül esett, hogy vajon a babaarc jellegeit túlzó mértékben kihangsúlyozó képek hogyan befolyásolják az emberek aranyosságészlelését. Képszerkesztô technikák segítségével tizenhárom autóról készült képet alakítottunk ki, amelyek a babaséma jellegeit a nullától a körülbelül háromszoros torzitásig tartalmazták. A vizsgálatban részt vevö 259 felnốt személy feladata az volt, hogy megítélje, hogy az adott autót mennyire tartja aranyosnak, illetve egyes képpárok esetében ki kellett választania, hogy a megjelenô gépjármüvek közül melyiket választaná. Az aranyosságítélet feladatra adott válaszok egy fordított $U$ alakú haranggörbét rajzoltak ki, melynek csúcsán a babaséma arányait megközelitöleg kétszeresen torzító optimális eset áll, amely ennek értelmében az emberekbôl a lehetô legerôteljesebb reakciót váltja ki. A választásos feladatrész adataiból azt állapitottuk meg, hogy - a férfiakkal összehasonlítva - a nók számára valamivel fontosabb tényezố az autóvásárlás során, hogy az autó megjelenése aranyosnak hasson, bár a válaszok eloszlását tekintve egyik nem sem választotta szívesen az aranyosabbnak itélt autót. A vizsgálat eredményei új fejezetet nyitnak a babaséma kutatásának irányában, hiszen az optimum számos ígéretes kutatási és alkalmazási lehetôségre világít rá.
\end{abstract}

Kulcsszavak: babaséma, optimum, autóarc, szupernormális inger 


\section{IRODALMI BEVEZETŐ}

\section{A jelen kutatás irányai}

A babákat legtöbbünk aranyosnak találja, ha találkozunk velük, ösztönösen ellágyul a hangunk, mosolyra húzódik a szánk, felemeljük és ringatjuk ôket. A jelenség természetesen evolúciós tốrôl fakad, és elsôsorban az utód túlélését szolgálja. Hatásai azonban sokrétúbbek és messzebbre nyúlnak annál, mint ahogyan azt legtöbbünk gondolná, hiszen befolyással lehet ítélóképességünkre, preferenciáinkra, teljesítményünkre, agyi múködésünkre, elsố benyomásainkra, de akár vásárlási szokásainkra is. Érdekes felvetés lehet tehát, hogy vajon mit és miért mond el a csecsemố csupán fizikai megjelenésével magáról, milyen információkkal szolgál állapotáról és milyen motivációt indít el bennünk. Kutatásunkban arra fogjuk keresni a választ, hogy a bébisémák hogyan generalizálhatóak élettelen tárgyakra, valamint, hogy a jellemzók méretei még extrém méretú torzítások esetén is preferenciát váltatnak-e ki vagy megállapítható egy optimális szint.

\section{Az arc kiemelt szerepe, evolúciós alapok}

A testreprezentáció kialakulása során azt tapasztalhatjuk, hogy az újszülötteknél az arc esetében már sokkal korábban megjelenik a vizuális téri reprezentáció, mint egyéb testrészeket tekintve. A csecsemốk már néhány perccel születésüket követôen érzékenyek az arcszerú mintázatokra, és tekintetüket is jóval gyakrabban fordítják effelé. Vizsgálatok bizonyítják, hogy a babák sokkal nagyobb preferenciát mutatnak olyan sémaábrákra, melyek $\mathrm{V}$ vagy $\mathrm{T}$ elrendezésúek, tehát az emberi arc sémájához alkalmazkodnak, mint ahol ezeket fejjel lefelé látták. A gyermekek tehát feltehetôleg „innát humán arcsémával születnek" (Lábadi, 2011). Az emberi arcnak tehát kiemelt szerepe van a test reprezentációjában.

Konrad Lorenz vetette fel elôször, hogy bizonyos fizikai jellemzők, mint a nagy fej, a gömbölyded arc, a magas homlok, a kis orr és száj, valamint a nagy szem - amelyek a kisbabák arcának jellemzôi - vonzónak, aranyosnak hatnak, és gondozóviselkedésre irányuló motivációt aktiválnak a felnôttekben (Lorenz, 1943). Magyarázata szerint a humán szociális kogníciónak ez a jellegzetessége evolúciós szempontból az utód túlélési esélyeinek növelésében van. Ezek szupernormális ingerként jelenhetnek meg ebben az esetben, tehát feltételezhetố, hogy egy olyan ingerről beszélhetünk, ahol az alanyok nagyobb preferenciát mutatnak, ha az inger a természetes formától eltérôen jelenik meg (Staddon, 1975).

\section{A séma különbözó hatásai}

Egy friss kutatás (Glocker, Langleben, Ruparel, Loughead, Gur, és mtsai, 2009) elsôsorban azt helyezi fókuszba, hogy a babák arcának megváltoztatása és manipulálása milyen változásokat indít be a felnôttekben az aranyosság megítélésében és a gondo- 
zás motivációjában. A kísérletben az inger babákról készült kép volt, amelyet különbözô tengelyek mentén manipuláltak, ezáltal pedig három feltételt hoztak létre: erôsen manipulált (gömbölyded arc, nagy szem, kis száj és arc), nem manipulált és negatív irányba manipulált (vékony arc, kis szemek, nagy orr és száj) képeket. A kísérlet vezetôi szignifikáns eltérést találtak a magasan és az alacsonyra motivált képek között, tehát a résztvevôk sokkal aranyosabbnak értékelték és szívesebben gondozták volna azokat a csecsemóket, amelyeknek a fotói a babasémákat kihangsúlyozó képek voltak. Ezek az eredmények mind a férfi, mind a nôi résztvevôknél megfigyelhetôk voltak, bár a gondozás feltételben a nôk valamivel magasabb motivációs értéket mutattak.

A sémák széles körü hatását bizonyítja, hogy egy másik kutatás (Little, 2012) már nemcsak csecsemóképek, hanem felnôtt emberek és macskafotók manipulálásával is foglalkozik. Az eredmények azt is megmutatták, hogy összességében a „babásított képek”, valamint a babákról és az állatokról készült képek aranyosabbnak hatnak, mint a felnôttek fotói. Korábbi kutatásokkal ellentétben, melyek szerint a fiatal nôk érzékenyebbek a babaarcokra, itt nemi különbség nem jelent meg.

Amikor Lorenz felvetette a Kinderschema elméletét, nem szabott meg idôbeli határt a csecsemôkorra. Ezt vizsgálta egy kínai kutatás (Luo, Li és Lee, 2011), amely szerint a rokonszenvesség és az attraktivitás értékelésében a kor elôrehaladtával vagy drasztikus csökkenés mutatható ki, vagy e két érték a kor növekedésével fokozatosan veszíti el a hatását. A kutatásban különbözó életkorú személyeket ábrázoló képeket kellett értékelniük a kísérleti alanyoknak a rokonszenvesség és az attraktivitás szempontjából. Az eredmények ebben a vizsgálatban is igazolták, hogy a csecsemôarcokat általában magasabb pontszámokkal értékelték, mint az egyéb életkori csoporthoz tartozókat. A vizsgálat megmutatta továbbá, hogy a bébiséma hatása körülbelül négy és fél éves kortól megszúnik.

A legtöbb vizsgálat a fiatal felnôttek, illetve felnôttek korcsoportjából választja a résztvevőit. Bár, ahogy ezt láttuk, a kisgyermekek babaarca egy idô után elveszti különleges hatását, érdekes kérdés, hogy vajon a kisgyermekekre milyen hatással lehet a babaséma prezentálása. Természetesen az ô esetükben a gondozás motivációját vizsgálni kevésbé releváns kérdés, az aranyosság megítélése azonban kecsegtethet érdekes eredményekkel. Egy friss kutatás (Borgi, Cogliati-Dezza, Brelsford, Meints és Cirulli, 2014) 3-6 éves gyermekek vizsgálata során szerette volna megfigyelni, hogy az aranyosság megítélése korán megjelenik-e, és amennyiben igen, akkor ez vajon tartós tulajdonság, vagy mutatkoznak változások a fejlôdés során. A kísérlet során explicit módon, aranyosság megítéltetéssel és implicit módon, tekintetmintázatokkal is igazolni kívánták a hatást.. Az eredmények azt mutatták, hogy már nagyon korai fázisban megjelenik mind a tekintet fixációjában, mind az aranyosság megítélésében egy preferencia a babák arcának speciális jellegeire, és ez nemcsak emberi, hanem állati arcok esetén is nyilvánvaló. A tekintet orientációjában a sorrend a szem, majd az orr és a száj volt, amely szintén reflektált a bébiséma jegyeire, hiszen a gyermekek tovább nézték a pozitívabb irányba mozdított képeket, mint azokat, ahol ezeket a jellemzóket nem emelték ki (Borgi és mtsai, 2014).

Érdekes módon bizonyos készségeinket is megváltoztathatják az aranyos képek egy adott feladatot megelôzốen. Egy japán kutatásban (Nittono, Fukushima, Yano és Moriya, 2012) szignifikánsan magasabb teljesítményt mutattak a résztvevôk egy finom- 
motoros feladatban aranyosabb képek nézegetése után (kölyök macskák és kutyák), mint kevésbé aranyos képek után (felnôtt kutyák és macskák), ez a teljesítményjavulás pedig még vizuális keresési helyzetekben is megfigyelhetô volt. Az eredmények összefüggésben állnak azzal, hogy az arcok motivációs hatása miatt a résztvevôk nagyobb gondot fordítottak a feladatok végrehajtására. Egy reakcióidôt mérô feladat eredményei továbbá megmutatták, hogy a globális preferenciában csökkenést eredményezhetnek a kölykökrôl készült képek, ami a képek figyelemirányító hatásával függ öszsze.

\section{A szépség megitélésének különféle mutatói, jellemzôi - párhuzamok a babaséma fóbb jegyeivel}

Ahogyan az állatvilágban, úgy az ember esetében is kiemelkedôen fontos, hogy sikeresen felmérje partnere reprodukciós készségeit. A nôk esetében ez leginkább a termékenységgel függ össze, amelynek egyik legfőbb előrejelzője a partner fiatalsága. A férfiak tehát olyan testi mutatókat figyelnek választásukkor, amely a partner fiatalságát mutatja. Ez az arcarányok révén észlelhetô a legjobban: kis orr, nagy szemek, kis áll, telt ajkak. A neoténia, vagyis hogy egy felnôtt egyed a fajra jellemzó fiatalabb jegyeket megtartja, egy szupernormális mutatóként értelmezhetô tehát a párválasztásban. Egyszóval a férfiak azokat a nôi arcokat preferálják, amelyek fiatalabbnak tûnnek, mint valójában (Meskó, 2010). A szépség megítélésében szintén a babák arcához hasonló jegyek kapnak kiemelkedô szerepet. A nôk arcának attraktivitását alapvetôen három fontos jellemzô határozza meg: az arc szimmetrikussága, átlagossága, valamint bizonyos egyedi vonások mérete (nagy szem, feltûnô arccsont, vékony orr és áll, valamint vastag száj). A szociális életben a szépségnek, rengeteg elônyét ismerjük, emellett a kérdést evolúciós szemszögbool vizsgálva, a szépség és az egészségesség a termékenység jó elôrejelzője lehet (Baudouin és Tiberghien, 2004).

Megfigyelhettük, hogy a nôk, akik a legtöbb társadalomban elsôdlegesen töltik be a gondozó szerepét, erôs motivációs és érzelmi hatást mutatnak a babákról készült fotókat nézve, különösképpen akkor, ha ezek a motivációs jegyek ki vannak hangsúlyozva. Érdekes módon további kutatások adataiból kiderül, hogy azoknál a fotóknál, amelyeken a séma jegyeit kihangsúlyozó torzított csecsemók voltak, általában az aranyosság és az attraktivitás korrelált azzal, hogy okosabbnak, egészségesebbnek, barátságosabbnak és boldogabbnak értékelték ôket a kísérleti személyek (Glocker, Langleben, Ruparel, Loughead, Valdez és mtsai, 2009). A pozitív jellemzók társítása hasonlóan jelenik meg akkor is, ha egy számunkra megnyerô külsejû személlyel találkozunk, akit általában szintén humorosabbnak, intelligensebbnek és szociábilisabbnak tartunk másoknál (Agthe, Spörrle és Maner, 2011). A séma fontosságára ebben a kontextusban egy másik kutatás is felhívja a figyelmet, amelyben a különféle babaarcok megítélésében mind a férfiak, mind a nôk alacsonyabb értékeket adtak, és kevesebb ideig nézték az abnormális csecsemôket (pl: bőrproblémák, Down-kór), mint egészséges társaikat (Yamamoto, Ariely, Chi, Langleben és Elman, 2009). A „babaarc” sztereotípia szerint a felnôttek emellett azokat a személyeket, akiknek az arca a legjobban hasonlít egy csecsemố arcára, alázatosabbnak, melegszívúbbnek és antiszociális viselkedésre kevésbé 
hajlamosnak tartják, bár hátulütők is megjelennek, úgymint a megbízhatatlanság és a naivitás (Little, 2012).

\section{Felhasználás - a hatás élettelen tárgyakon}

A babasémák felhasználása számos területen megmutatkozik, hiszen az emberek magasabb preferenciát mutattak, nemcsak a manipulált babaarcokra, hanem az újszülött állatok, az aranyos rajzfilmfigurák és a babaarcú emberek iránt is. Egyértelmúen következik ebból, hogy a reklámiparban a babasémák felhasználása kiemelt szerepet kap. Az egyik legfontosabb „belsô figyelemmegragadóként” tartják számon a területen, hiszen a nevelés motivációja miatt mindkét nemre különösen nagy hatással van (Rossiter, Langner és Ang, 2003).

Egy játékbaba látványa például lelki életünkre és hangulatunkra is befolyással lehet, ezzel kapcsolatban egy vizsgálatban megmutatták (Jacob, Rodenhauser és Markert, 1986), hogy azok a nôk, akiknél gyakran jelentkeznek a szomorúság, az idegesség és a magány jelei, általában boldogságról és magabiztosság érzésérôl számoltak be a Cabbage Patch Kid (népszerú amerikai játékfigura) megvásárlásának hatására.

Egy vizsgálatban azonban azt is kimutatták, hogy a nagyobb érdeklődés nemcsak babaszerú tárgyak, hanem például autók esetében is megfigyelhetô (Miesler, Leder és Herrmann, 2011). A „bogárhátú” és a Mini Cooper sikerét igazolja, hogy érdemes volt az autó „arcára” figyelmet fordítani. A kocsi fényszórói szemre, az autó rácsozása egy emberi orra, míg a szellózoónyílás szájra emlékeztetnek. A vizsgálat során kimutatták, hogy amikor az autó fényképét a babaarchoz hasonló módon manipulálták (nagyobb fényszórók, összehúzott rácsozás és vékonyabb szellốzônyílás), a vizsgálati személyek szignifikánsan magasabb preferenciát mutattak a manipulált autókra az eredetiekkel szemben (Miesler és mtsai, 2011).

\section{A KUTATÁS KÉRDÉSEI}

A jelen kutatás célja a babaséma hatásainak vizsgálata felnôtt személyek aranyosságmegítélésére. A szakirodalom áttekintése után megállapíthatjuk, hogy a séma legfőbb jegyei élettelen tárgyak, például autók esetén is befolyásolják észlelésünket (Miesler és mtsai, 2011), azonban azzal kapcsolatban még nincsenek mért eredmények, hogy a séma relatív méreteit megnövelve milyen hatás váltható ki az ítéletekre. A kutatás arra helyezi a legnagyobb hangsúlyt, hogy a séma erôteljes, eltúlzott megjelenései milyen aranyosságértékeket váltanak ki a vizsgálati személyekben. Tehát bár vizsgálatunk igyekszik megismételni a korábbi eredményeket és a babák arcához hasonló torzítást is elkészítettük, feltételezéseink szerint az ennél extrémebb mértékú, pozitív irányú változtatások magasabb aranyosságítélet-értéket hívnak elő:

- Hipotézisünk szerint megállapítható egy optimális szint a babaséma jegyeit túlzó módon hangsúlyozó autók esetében, amely után az aranyosságítélet-értékek egyfajta csökkenést mutatnak (H1). 
- Vizsgáljuk a nemi különbségek meglétét is, hipotéziseink szerint, mivel a nók a babaarcokat a korábbi kutatásokban (Parsons és mtsai, 2011) aranyosabbnak ítélték meg, mint a férfiak, általánosságban ezt a tendenciát autók esetén is mutatják (H2).

- Ezen kívül lakóhely tekintetében különbséget teszünk kisvárosi és nagyvárosi résztvevók között, feltételezésünk szerint a városi ember egy átlagos napja során több gépjármúvel találkozik, emiatt nagyobb különbséget tud tenni az egyes képek között. A babaséma univerzális hatása miatt azonban itt különbségre nem számítunk (H3).

- Ahogyan azt a fentiekben tárgyalt vizsgálatok is megerôsítik, az aranyosság észleléséhez általában pozitív érzelmek párosulnak (Little, 2012). Érdekes kérdés megvizsgálni, hogy autók esetében az aranyosságítéletek kapcsolódnak-e a vásárlási hajlandósághoz. Hipotézisünk szerint a babás jellegeket kihangsúlyozó autókat szívesebben választják a vizsgálati személyek. A kérdésben elsôsorban nemi különbségeket feltételezünk, ahol feltételezhetôen az állítás elsôsorban a nôkkel kapcsolatban jut érvényre (H4).

- A választásos feladatok kialakítása során felhasználjuk az extrém esetet ábrázoló képet is, ebben az esetben a nemi különbségek eltúnésére, tehát egyöntetú aranyosságítélet-csökkenésre számítunk (H5).

\section{MÓDSZERTAN}

\section{Résztvevók}

A vizsgálatban összesen 259 személy vett részt. A nemi megoszlás a mintában nem tekinthetô optimálisnak, hiszen a 198 nôi kitöltôhöz csupán 61 férfi résztvevô párosult. A vizsgálati személyek átlagéletkora 27,33 volt, az alanyok különbözô korosztályokból, 18-tól 64 éves korig képviseltették magukat. Az emberek legnagyobb része internetes közösségi hálózatok útján került be a vizsgálatba (1. táblázat).

1.táblázat. A résztvevôk nemek szerinti megoszlása az egyes korcsoportokban

\begin{tabular}{|l|c|c|c|c|c|c|c|c|c|c|}
\hline $\begin{array}{l}\text { Életkori } \\
\text { csoportok }\end{array}$ & \multicolumn{2}{|c|}{$18-26$} & \multicolumn{2}{c|}{$27-35$} & \multicolumn{2}{c|}{$36-44$} & \multicolumn{2}{c|}{$45-54$} & \multicolumn{2}{c|}{$55-64$} \\
\hline Nemek & Férfi & Nố & Férfi & Nố & Férfi & Nố & Férfi & Nố & Férfi & Nố \\
\hline $\begin{array}{l}\text { A csoportok } \\
\text { létszáma }\end{array}$ & 46 & 126 & 6 & 37 & 4 & 17 & 4 & 12 & 1 & 6 \\
\hline
\end{tabular}

\section{Eszközök}

Kutatásunk fókuszpontjába azért az autó arca került, mert ez lehetôséget biztosít arra, hogy a tesztelés során a vizsgálati személyek számára ne legyen egyértelmú, hogy milyen kísérleti manipulációban vesznek részt. A választások során így feltehetôleg minél inkább nem tudatos gondolkodási folyamatok érvényesülnek. További szempont volt, hogy az autók jellegeinek túlzott manipulálása valószínúleg kisebb eséllyel vált 
ki természetellenes érzést az alanyokban. A kérdôív kitöltése során a résztvevôk tizenhárom képrôl alkottak véleményt. A képek színesben, elölnézetból ábrázoltak egy középkategóriás autónak számító, ezüstszínú 2011-es Honda Accord Sedant, amelyrôl azonban a márkára utaló jegyeket eltávolítottuk, hogy az ne befolyásolja az alanyok ítéletalkotását. A képek színesben, jó minôségben, 1024×768-as felbontásban kerültek a személyek elé. Az autó típusának kiválasztásával kapcsolatban egy korábbi kutatás (Miesler és mtsai, 2011) eredményei arra engednek következtetni, hogy a babaséma szerinti torzítás bármilyen autó esetében jól múködhet, hiszen ebben a vizsgálatban 16 különbözó márkájú és árkategóriájú (BMW, Mercedes, Fiat, Mini stb.) autót használtak fel, mégis egy irányba mutattak a kutatás tanulságai (a „babasémás autókat” aranyosabbnak találták a vizsgálat résztvevôii).

Mindegyik kép esetében a manipuláció az Adobe Photoshop CS nevú program felhasználásával került lebonyolításra. Az autó azon három elemét torzítottuk, amely összefüggésbe állítható az emberi arc főbb jegyeivel. Ebben az értelemben a fényszóró a szemnek, a rácsozás az orrnak, a szellốzônyílás pedig a szájnak felel meg. Az optimális méretek meghatározása a szakirodalommal összefüggésben került megtervezésre, amely mind az autók, mind a babák arcának fizikai jellemzôinek összevetésével alakította ki a megfelelő arányokat (Miesler és mtsai, 2011).

Elsố lépésként a kiinduló képbôl (az autó eredeti helyzetben, márkajelzések nélkül) alakítottuk ki a „babaarcú autót”, figyelembe véve a babaséma jellegeit. A procedúra során az autó fényszóróinak relatív méreteit 20\%-kal nagyítottuk fel, a rácsozásét azonban $20 \%$-kal csökkentettük. Erre azért volt szükség, mert a baba szeme a felnôtt archoz képest aránylag nagy, orra azonban valamivel kisebb. A szellôzônyílás szélességét 20\%-kal vettük vissza, miközben a magasságát 20\%-kal megnöveltük, hiszen a babák szája bár viszonylag kicsi, az ajkuk valamivel vastagabb, mint a felnôtteknek (Miesler és mtsai, 2011). Fontos megemlíteni, hogy mivel a kutatásban csupán egy autó különbözô mértékú torzításai jelentek meg a vizsgálati személy elôtt, a 20\%-os torzítás csak megközelítôleg hordozza magán a babaséma jegyeit, és nem tekinthetô a séma abszolút megtestesítôjeként. A képrôl azonban elmondható, hogy a különbözô mértékú manipulációk közül valószínúleg ez áll a legközelebb a séma eredeti arányaihoz.

A további képek kialakítása hasonló technikák bevonásával történt, azonban más méretarányok felhasználásával. A következô kialakított kép a végsố esetet ábrázolta, amelynél a legfőbb célunk az volt, hogy a torzítás minél eltúlzottabbnak, minél extrémebbnek hasson. Ennek érdekében a korábban 20\%-kal módosított kép után egy, azt a háromszorosára manipulált, a fóbb jellegek relatív méreteit $60 \%$-kal növelố vagy csökkentô feltétel jött létre. Az autó látványa ezzel az átalakítással gyökeresen megváltozik, és meglehetôsen szélsôségesen ábrázolja a jellegeket.

A maradék tíz fotó átmeneteket képez a kiinduló kép és 20\%-kal manipulált állapot, illetve a $20 \%$-os torzítás és a végleges eset között. A kiinduló kép után $5 \%$-os torzítást végeztünk a következô fotó kialakításához, majd egyenként haladva a módosításokat az elôzôhöz képest mindig további 5\%-kal növeltük. Ha sorrendbe állítjuk az így elkészült tizenhárom képet, akkor a babaarchoz legjobban hasonlító paramétereket az ötödik fotónál figyelhetjük meg. Az ezt követô állapotok mind eltúlozzák a babaséma egyes jellegeit, kutatásunkban ezeknél a manipulációknál számítunk magasabb aranyosságítélet-értékekre (1-13. ábra). 


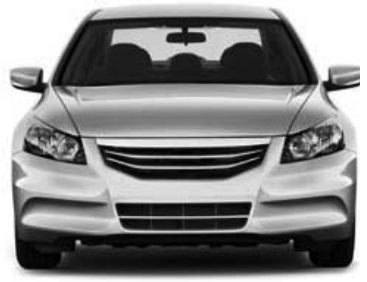

1. ábra. Az eredeti kép

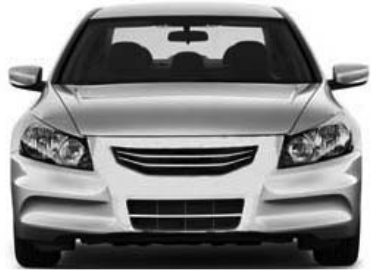

4. ábra. $115 \%$-os torzítás

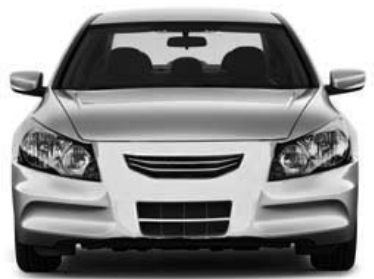

7. ábra. 130\%-os torzítás

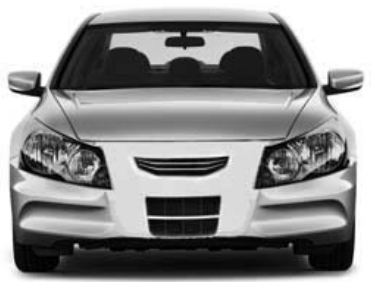

10. ábra. $145 \%$-os torzítás

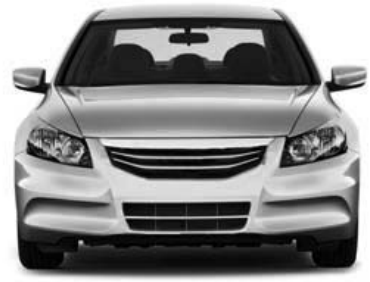

2. ábra. $105 \%$-os torzítás

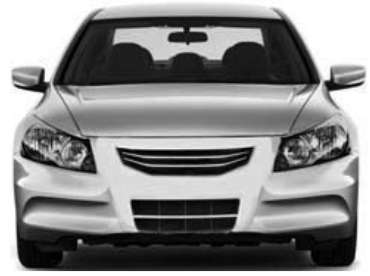

5. ábra. 120\%-os torzítás

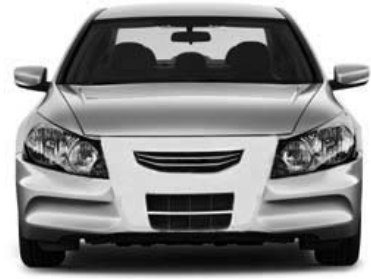

8. ábra. $135 \%$-os torzítás

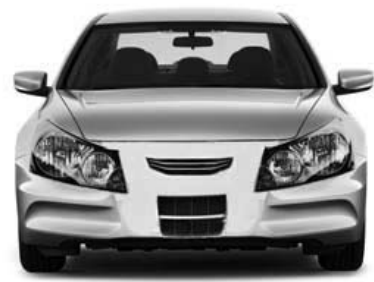

11. ábra. $150 \%$-os torzítás

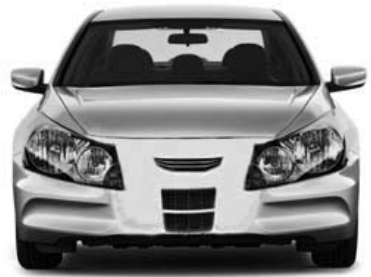

13. ábra. $160 \%$-os, legmagasabb torzítás

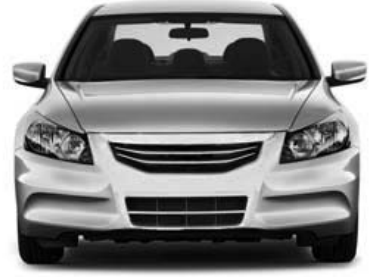

3. ábra. $110 \%$-os torzítás

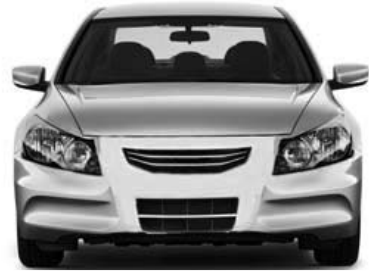

6. ábra. $125 \%$-os torzítás

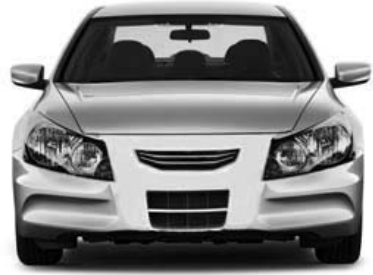

9. ábra. $140 \%$-os torzítás

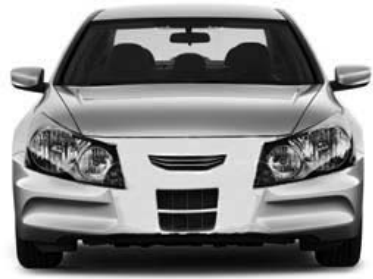

12. ábra. $155 \%$-os torzítás 


\section{Eljárás}

A vizsgálatban részt vevớket egy online kérdéssor kitöltésére kértük fel. A vizsgálatot megelôzôen tájékoztattuk az alanyokat a kitöltés önkéntes és anonim módjáról, az adatfeldolgozás etikai elveirôl, valamint a részvétel feltételeirôl. A kutatás céljáról a kérdéssort megelőzóen homályos felvilágosítást adtunk, kivédve ezzel a manipulációk alapelveinek szem elốtt tartását a válaszadás során. A vizsgálat így „A preferencia motivációs tényezôi" címet kapta, és eleinte csak annyit árultunk el róla, hogy a választásaink mögött megbújó motivációs hatásokat szeretnénk feltérképezni, továbbá azt, hogy ezek hogyan függnek össze evolúciós örökségünkkel. A vizsgálatban kizárólag a tizennyolcadik életévüket betöltố alanyok vehettek részt.

A „bevezetô” kérdések (nem, életkor, lakhely) után a konkrét vizsgálatra tértünk rá. A babaséma optimumának meghatározásához a résztvevốknek az elsố feladatrészben, tizenhárom képrôl kellett véleményt alkotnia. Az autók fotóinak sorrendjénél az elsôdleges szempont az volt, hogy a minimális különbség, amely a szakirodalom alapján, az alanyok válaszaiban biztosan szignifikáns változást eredményez, 20\%-os, tehát megközelítôleg egy „babasémányi” (Miesler és mtsai, 2011). Ezzel a módszerrel elkerülhetố a vizsgálat túlzott monotonitása. A képek így 30\%-os különbséggel követték egymást. Az alanyoknak a bemutatott képek esetében meg kellett határozniuk, hogy a különféle autókat mennyire találják aranyosnak. Ítéletüket egy hétfokú Likert-féle skála segítségével kellett meghozniuk, melyben a tartomány határai a következôk voltak: 1 - „egyáltalán nem tartom aranyosnak”, 7 - „nagyon aranyosnak tartom”.

Az aranyosság hat a preferenciáinkra, de hogy ezek hogyan és milyen irányban hatnak vásárlási/választási szokásainkra, még kérdéses. Elsôsorban ezt az összefüggést hivatott vizsgálni a kérdôív 2. fố része, amelyben ismét a fentiekben megismert 13 kép került górcsố alá, ebben a helyzetben azonban páros bemutatásban. Az elôzôhöz hasonlóan itt is 13 kérdésbốl állt a feladatsor, melynek elsố eleme az eredeti kép mellé a babasémához legjobban hasonlító autót állította. A következô 2 pár az eddig megszokottnál nagyobb változtatásokat is bemutat, hiszen amíg a babasémaszerú és a végsố eset között a differencia negyven, addig az eredeti és az utolsó kép között az eltérés már $60 \%$-os (2. táblázat). A maradék 10 fotópár olyan autókat állított egymás mellé, amelyek között a differencia 5\%-tól, 20\%-ig váltakozott. Ebbe az összeállításba csak azok a képek kerültek, ahol a feltételezéseink szerinti optimális szint a lehetố legnagyobb valószínúséggel fordul elố. Mivel a korábbi eredmények megmutatták, hogy az eredeti verziónál nagyobb aranyosságértékeket vált ki a babásított arc (Glocker és mtsai, 2009), az összehasonlító vizsgálatba csak a babaséma arányait megközelítôleg legjobban lemodellezó, illetve az azon túlmutató autók kerültek (3. táblázat).

2. táblázat. Az elsố három képpár elrendezése

\begin{tabular}{|l|c|c|c|c|c|c|}
\hline Párok sorszáma & \multicolumn{2}{|c|}{ 1.pár } & \multicolumn{2}{c|}{ 2.pár } & \multicolumn{2}{c|}{ 3.pár } \\
\hline Bemutatott képpárok & 1. & 5. & 5. & 13. & 1. & 13. \\
\hline
\end{tabular}

A fotókhoz csatolt kérdés a következôképpen hangzott: „Ön melyik autót választaná/vásárolná meg?” A 120\%-os torzítástól a 140\%-ig a képek minden lehetséges 
3. táblázat. Az érzékenyebb különbségeket is bemutató képpárok elrendezése.

A különbség a képek között 5\%-tól 20\%-ig terjed. A babasémaszerú kép az 5. sorszámot, az optimum a 9-est kapta

\begin{tabular}{|c|c|c|c|c|c|c|c|c|c|c|c|c|c|c|c|c|c|c|c|c|}
\hline Párok sorszáma & \multicolumn{2}{|c|}{4.} & \multicolumn{2}{|c|}{5.} & \multicolumn{2}{|c|}{6.} & \multicolumn{2}{|c|}{7.} & \multicolumn{2}{|c|}{8.} & \multicolumn{2}{|c|}{9.} & \multicolumn{2}{|c|}{10.} & \multicolumn{2}{|c|}{11.} & \multicolumn{2}{|c|}{12.} & \multicolumn{2}{|c|}{13.} \\
\hline Bemutatott képpárok & 5 & 6 & 5 & 7 & 5 & 8 & 5 & 9 & 6 & 7 & 6 & 8 & 6 & 9 & 7 & 8 & 7 & 9 & 8 & 9 \\
\hline
\end{tabular}

párosításban megjelentek a vizsgálati személyek elôtt. Bár ez sokszor alig észrevehetố különbségeket eredményezett, a feladat a képek alaposabb monitorozását, részletesebb megfigyelését kívánta meg a résztvevốktôl, hiszen a bemutatott autók közül egyet mindenképpen választaniuk kellett. A sorrend alapelve a fokozatosság volt, a feladatot a babaarcú autó négy párosa kezdte, majd a 125\%-kal módosított kép mellé három, a 130-as mellé 2, végül a 135\%-kal felnagyított autó mellé egy kép került, ezáltal minden pár egyszer jelent meg a vizsgálati személyek elôtt, és minden esetben kifejezték véleményüket.

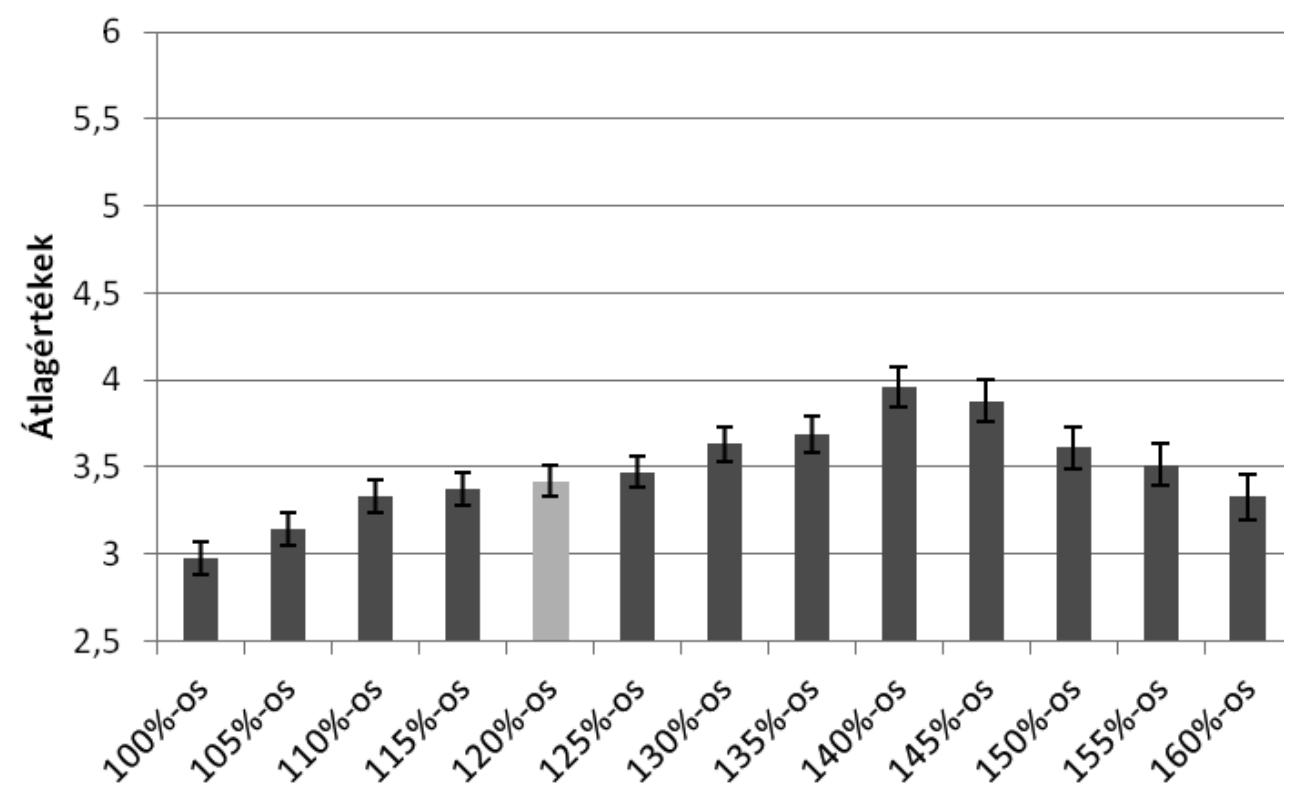

14. ábra. A képekre adott aranyosságértékelési válaszok átlagának grafikus ábrázolása a standard hiba feltüntetésével. A 120\%-os torzítás hordozza legjobban a babaséma arányait, az értékek pedig a 140\%-os képig növekednek, majd csökkenést mutatnak 
A kérdőív befejeztével lehetôséget adtunk a kitöltôknek arra, hogy bepillantást nyerjenek a kutatás „kulisszái” mögé és a kutatás valódi céljáról is tájékoztattuk ôket (I. melléklet). Erre azért volt szükség, mert a vizsgálat elején a kísérleti személyek egy félrevezetés áldozatai lettek, mert nem szerettük volna, ha a babasémával kapcsolatos információikat választásaik során is felhasználják. Fontos kiemelni, hogy a vizsgálati személyek számára nem volt expliciten kifejezve, hogy melyik az eredeti kép, amelyhez viszonyítva meg kell hozniuk az ítéleteiket, így nem voltak tisztában azzal, hogy melyik kép hasonlít legjobban a babasémára, és melyek azok, amelyek ezeket a jellegeket még jobban kihangsúlyozzák.

\section{EREDMÉNYEK}

A vizsgálati személyek adatai online módon érkeztek be, amit a könnyebb kezelhetôség érdekében Excel-táblázat formájában rögzítettünk. A statisztikai elemzés az SPSS 20.0 program segítségével valósult meg.

Az optimumra elôször a leíró statisztikák alapján következtettünk (H1). Az egyes képekre adott válaszok átlagának értelmében az eredeti kép 2,98-as, a 20\%-os módosítás által készült kép 3,42-es, az extrém mértékben torzított kép pedig 3,33-as értéket kapott. Ha a képeket növekvô sorrendbe állítjuk, akkor az átlagértékek egészen a kilencedik képig exponenciálisan emelkednek, a 140\%-os torzítással készült esetében a legmagasabb tehát az átlag, hiszen 3,96-os érték kapcsolódik hozzá. Innen az átlagértékek folyamatos csökkenést mutatnak egészen az utolsó, azaz a 160\%-kal torzított képig (14. ábra, 4. táblázat). A következtetéseinket innentôl az ismételt méréses ANOVA teszt eredményei alapján hoztuk meg.

4. táblázat. A képekre adott válaszok átlaga és szórása

\begin{tabular}{|c|c|c|}
\hline $\begin{array}{l}\text { A képek } \\
\text { sorszáma }\end{array}$ & Átlagok & Szórás \\
\hline 1. kép & 2,98 & 1,510 \\
\hline 2. kép & 3,14 & 1,497 \\
\hline 3. kép & 3,33 & 1,473 \\
\hline 4. kép & 3,37 & 1,508 \\
\hline 5. kép & 3,42 & 1,448 \\
\hline 6. kép & 3,47 & 1,410 \\
\hline 7. kép & 3,63 & 1,590 \\
\hline 8. kép & 3,69 & 1,670 \\
\hline 9. kép & 3,96 & 1,828 \\
\hline 10. kép & 3,88 & 1,888 \\
\hline 11. kép & 3,61 & 1,886 \\
\hline 12. kép & 3,51 & 1,944 \\
\hline 13. kép & 3,33 & 2,090 \\
\hline
\end{tabular}




\section{Az eredmények ismételt méréses ANOVA-val}

Mindenekelôtt arra szerettük volna megkeresni a választ, hogy az egyes képek során elvégzett manipulációs folyamatok valóban szignifikáns változást hoznak-e a vizsgálati személyek válaszaiban. Az ismételt méréses ANOVA vizsgálat eredményei beigazolták elôzetes sejtéseinket, hiszen a manipulációnk szignifikáns különbséget eredményezett a válaszokban, tehát megállapíthatjuk, hogy a jellegek növelése befolyásolta a résztvevôk aranyosságészlelését $\mathrm{F}(3,561)=11,101, \mathrm{p}<0,001, \eta \mathrm{p}^{2}=0,041$.

Elơzetesen úgy véltük, hogy a nôk a férfiakhoz képest magasabb pontszámokat fognak adni az aranyosságészlelési feladat során (H2). Lakóhely szerint is elkülönítettük a résztvevóket, így kisvárosi-falusi, illetve budapesti csoportokat kaptunk, amivel kapcsolatban úgy véltük, hogy - a babaséma hatásának egyetemlegessége miatt - nem lesz különbség (H3). Míg az utóbbi hipotézisünk beigazolódott, a nemek tekintetében a mi kutatásunk is azokat a vizsgálatokat támasztotta alá, ahol nem volt különbség a férfi-nôi válaszok között. Ennek értelmében a hatás független volt a nemektốl és a résztvevôk lakhelyétôl, amit két ízben is igazoltunk. Nem találtunk szignifikáns különbséget sem nemek között $\mathrm{F}(1)=0,966, \mathrm{p}=0,327, \eta \mathrm{p}^{2}=0,004$, sem a lakhelyre vonatkozóan $\mathrm{F}(1)=0,610, \mathrm{p}=0,436, \eta \mathrm{p}^{2}=0,002$, az átlagos tetszésben. Továbbá sem a férfiak és nôk között $\mathrm{F}(3,555)=1,274, \mathrm{p}=0,280, \eta \mathrm{p}^{2}=0,005$, sem a kisvárosi-falusi és budapesti lakosok között $\mathrm{F}(3,570)=1,007, \mathrm{p}=0,389, \eta \mathrm{p}^{2}=0,004$ nem találtunk szignifikáns interakciót. Tehát a férfiak és a nôk, valamint a kisvárosiak-falusiak és a budapestiek tetszési görbéjének lefutása között nincs szignifikáns különbség.

A vizsgálatunk elsốdleges célja egyfajta optimum megállapítása volt, vagyis a különbözó manipulációk során egy olyan eset kialakítása, ahol a válaszok a legmagasabb értéket mutatják. Hipotézisünk szerint eddig a pontig az értékek folyamatosan növekednek, innen azonban csökkenố tendenciát mutatnak (H1). Az egyes képek közötti pontos különbségekre, tehát az optimum megállapítására páronkénti összehasonlítások (post-hoc tesztek) és kontrasztvizsgálatok alapján következtettünk. A páronkénti összehasonlítás során minden képet az összes lehetséges kombinációban megvizsgáltunk, így összesen 78 eredmény született. Az optimum meghatározásához természetesen ennek a töredéke is elég. A négy „legfontosabb” kép összehasonlítása ismételt kontrasztos vizsgálat bevonásával történt.

Először a korábban autók esetében is igazolt (Miesler és mtsai, 2011) babaséma által keltett hatást vettük górcsố alá. Arra számítottunk, hogy az eredmény a mi adatbázisunkra is kimutatható lesz. A feltételezésünket bizonyította, hogy a kontrasztvizsgálat során szignifikánsan magasabb aranyosságértéket találtunk a babasémára legjobban hasonlító képre az eredeti autóval szemben $\mathrm{F}(1)=24,904, \mathrm{p}<0,001, \eta p^{2}=0,088$. Ezzel igazoltuk, hogy a korábban kimutatott változás az aranyosság-észlelésben a mi mintánk esetében is megjelenik (II. melléklet).

A kutatásunk újítása tehát egy „optimum” meghatározása lenne, ami a mi adatbázisunk alapján a kilencedik képnél, vagyis a babasémát megközelítô képhez képest plusz 20\%-kal megnövelt, 140\%-kal torzított autónál figyelhetô meg. Ahhoz, hogy a korábbi eredményekhez képest megnövekedett értékeket igazoljuk, a következô kontrasztvizsgálatot a babasémaszerú autó és a feltételezett optimális szinten torzított autó között végeztük el. Ebben az esetben arra számítottunk, hogy az optimális esetre fog- 
nak érkezni a magasabb aranyosságítéletek. A teszt alapján a hipotézisünk érvényre jutott, hiszen az „optimális autó” szignifikánsan magasabb pontszámokat kapott F (1) $=17,333, \mathrm{p}<0,001, \eta \mathrm{p}^{2}=0,063$ a „babaarcúval” szemben (II. melléklet).

Ahhoz, hogy az optimum állítás megerôsítést kapjon, szükség volt arra is, hogy megvizsgáljuk, hogy az extrém mértékú torzítás esetében az értékek valóban csökkenést mutatnak-e. Ehhez a kontrasztvizsgálatok során az optimumra és az extrém esetre kértük ki a próbát. A feltételezéseink erre az összehasonlításra is megerôsítést nyertek, hiszen az extrém eset az optimumhoz képest szignifikánsan alacsonyabb pontértéket mutatott az aranyosságmegítélés feladat során $\mathrm{F}(1)=24,818 \mathrm{p}<0,001, \eta \mathrm{p}^{2}=0,088$. A három kontrasztvizsgálatot együtt szemlélve megállapíthatjuk, hogy az optimális torzítás a babaséma arányainak kétszerese, vagyis a 140\%-kal manipulált autó esetében figyelhetố meg (H1) (II. melléklet).

A fent említett eredményeket Bonferroni-korrekcióval is alátámasztottuk, amely a kontrasztvizsgálattal összehasonlítva sokkal szigorúbban kontrollál az összehasonlítások során fellépó familywise hibára. Ennek értelmében a babasémás autó ( $\mathrm{M}=3,425$ $\mathrm{SD}=0,090)$ az eredetivel $(\mathrm{M}=2,985, \mathrm{SD}=0,094)$ összehasonlítva magasabb értéket kapott $(\mathrm{p}=0,000)$, az optimális $(\mathrm{M}=3,96, \mathrm{SD}=0,114)$ a babasémással $(\mathrm{M}=3,42, \mathrm{SD}=$ $0,090)$ összehasonlítva szintén szignifikánsan magasabb volt $(\mathrm{p}<0,001)$, végül az optimumot $(\mathrm{M}=3,96, \mathrm{SD}=0,114)$ az extrém esettel $(\mathrm{M}=3,33, \mathrm{SD}=0,130)$ összehasonlítva az extrém eset pontértékei szignifikánsan alacsonyabbak voltak $(\mathrm{p}<0,001)$. Tehát az eredményeink szigorú statisztikai feltételek mellett is bebizonyosodtak.

A teljes post-hoc és kontraszttesztek alapos tanulmányozása további fontos következtetések levonására adott lehetôséget, hiszen az egyes képek között más különbségeket is felfedeztünk, melyek közül azonban csak a legfontosabbakat tárgyaljuk. A post-hoc esetében az elsố kép $(\mathrm{M}=2,985 \mathrm{SD}=0,094)$ csak a második $(\mathrm{M}=3,135, \mathrm{SD}=0,093)$ $\mathrm{p}=1$, az utolsó elốtti $(\mathrm{M}=3,506, \mathrm{SD}=0,121) \mathrm{p}=0,074$ és az utolsó képpel kapcsolatban $(\mathrm{M}=3,328, \mathrm{SD}=0,130) \mathrm{p}=1$, nem mutatott szignifikáns különbséget, a többi kilenc esetben azonban minden esetben szignifikánsan alacsonyabb értéket mutatott. A babasémás kép $(\mathrm{M}=3,42, \mathrm{SD}=0,090)$ a fent említett eredményeken túl szignifikánsan magasabb értéket mutatott a második képpel $(\mathrm{M}=3,135, \mathrm{SD}=0,093)$ szemben $\mathrm{p}$ = 0,023, továbbá szignifikánsan alacsonyabb értéket állapítottunk meg akkor, amikor a tízedik képpel $(\mathrm{M}=3,880, \mathrm{SD}=0,117)$ hasonlítottuk össze $\mathrm{p}=0,039$. Az általunk megállapított optimális szint $(\mathrm{M}=3,96, \mathrm{SD}=0,114)$ csak a tízes $(\mathrm{M}=3,880, \mathrm{SD}=0,117) \mathrm{p}$ $=1$ és a tizenegyes képtôl $(\mathrm{M}=3,606 \mathrm{SD}=0,117)$ nem tért el szignifikánsan $\mathrm{p}=0,059$. A tizenhármas kép $(\mathrm{M}=3,33, \mathrm{SD}=0,130)$ szignifikánsan alacsonyabb pontértékekkel az optimális képen kívül a tízes képtôl tér el $(\mathrm{M}=3,880, \mathrm{SD}=0,117)$ p <0,001.

\section{A kényszerválasztásos feladat eredményei}

A kényszerválasztásos feladatrész során arra voltunk kíváncsiak, hogy az aranyosabbnak észlelt autók hogyan függnek össze a személyek autóválasztásával, amely során elsôsorban nemi különbséget feltételeztünk. A feladat két részes volt, melynek elsố részében három pár, az eredeti és a 20\%-os, a 20\%-os és az extrém eset, valamint az eredeti és az extrém eset jelent meg. A párosítások során arra számítottunk, hogy a nôk 
az elsố párosításban szignifikánsan többször választják a babasémához hasonlító autót, míg a hatás az extrém esetek bevonásával eltûnik, hiszen az utolsó kép már egyik nem számára sem lesz vonzó (H5). Az elsô pár esetében igazolódott az elvárásunk, hiszen a Pearson $\chi^{2}(1, \mathrm{~N}=163)=6,815, \mathrm{p}=0,009$ (kétoldali) $\varphi=0,162$ (III. melléklet). Ennek értelmében a nôk 2,333-szor nagyobb valószínúséggel választják a babasémás autót, mint a férfiak (15. ábra, 5. táblázat).

A másik két párnál, ahol az extrém feltételt is bevontuk, már nem a várakozásunknak megfeleló eredményeket kaptunk. A 120\%-os autót az extrémmel összehasonlítva a nôk szignifikánsan többször választották az extrém autót, mint a férfiak Pearson $\chi^{2}$ $(1, \mathrm{~N}=237)=7,407, \mathrm{p}=0,006$ (kétoldali) $\varphi=0,169$ (III. melléklet). Ugyanezt a helyzetet

5. táblázat. Az elsố pár esetében a $\chi^{2}$ - próba kereszttáblája

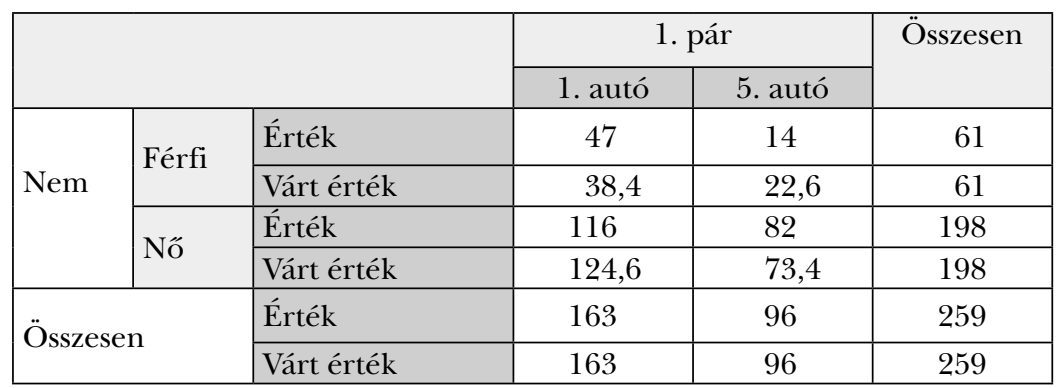

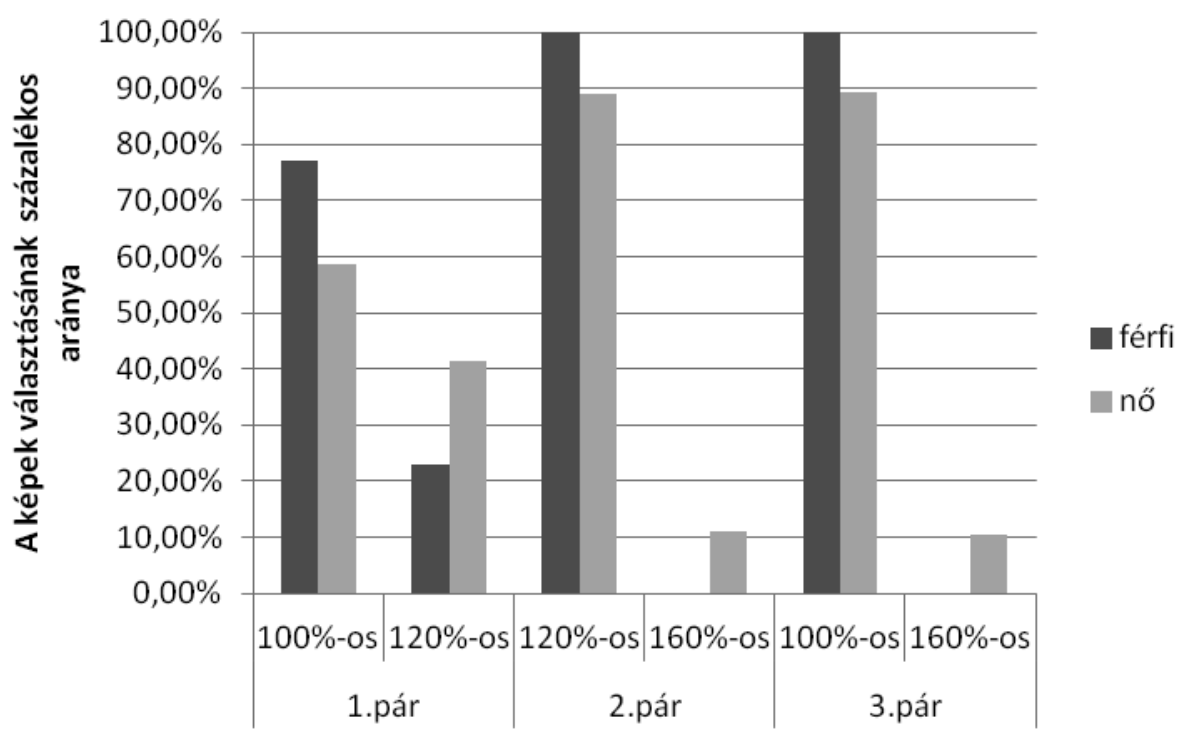

15. ábra. Az elsố három pár esetén a választások számának grafikus ábrázolása nemek szerint. Ebben a feladatrészben az egymás mellé állított képek között meglehetôsen nagy volt a különbség 
állapítottuk meg az eredeti és az extrém párosításban, hiszen itt is felülmúlták a nôk a férfiakat az extrém feltétel választásának gyakoriságában, Fisher-féle exact tesztet használva $\mathrm{p}=0,005$ (kétoldali) $\varphi=0,165$ (III. melléklet). A hatáserôsség-mutatók alapján mindhárom esetben meglehetôsen kicsi a nemek hatása.

A kényszerválasztásos feladat második részének eredményeit, ahol az autók a 120\%-os torzítástól kezdve a 140\%-ig minden lehetséges párosításban megjelentek, az alapján értékeltük, hogy az adott személy hány alkalommal választotta a két autó közül azt, amelyiket nagyobb mértékben manipuláltunk. A kérdésben itt is a nemi különbségekre voltunk kíváncsiak, amit független mintás t-próbával állapítottunk meg. Feltételezésünk szerint a nôk szignifikánsan gyakrabban választják azokat az autókat, amelyek a babákra jellemzó jegyeket nagyobb mértékben hangsúlyozzák ki (H4). A teszthez szükséges szóráshomogenitás feltétel nem teljesült $(\mathrm{p}=0,000)$, ezért korrigált t-próbával számoltunk. A próba eredményei alapján a nôk $(\mathrm{M}=12,56, \mathrm{SD}=2,85)$ szignifikánsan többször választották a nagyobb torzítással készült autókat a férfiakkal $(\mathrm{M}=11,43$, $\mathrm{SD}=2,04)$ szemben $\mathrm{t}(138,307)=-3,502, \mathrm{p}=0,001$, ami alátámasztja az elôzetes következtetésünket (IV. melléklet). A Cohen-féle hatásméret-mutató alapján $(\mathrm{d}=0,51)$, közepesen erôs hatásra következtethetünk. A válaszok eloszlásából azonban összességében arra következtethetünk, hogy a nagyobb mértékú torzítás nem vonzza magával a vásárlási kedv növekedését. Diszkrepancia húzódik meg tehát az aranyosságértékelés és a vásárlási motiváció között, hiszen bár a nemi különbségek szignifikánsak voltak, a nôk esetében is megfigyelhetô volt a tendencia, miszerint kisebb arányban választották a nagyobb mértékben torzított autókat (16. ábra, 6. táblázat).

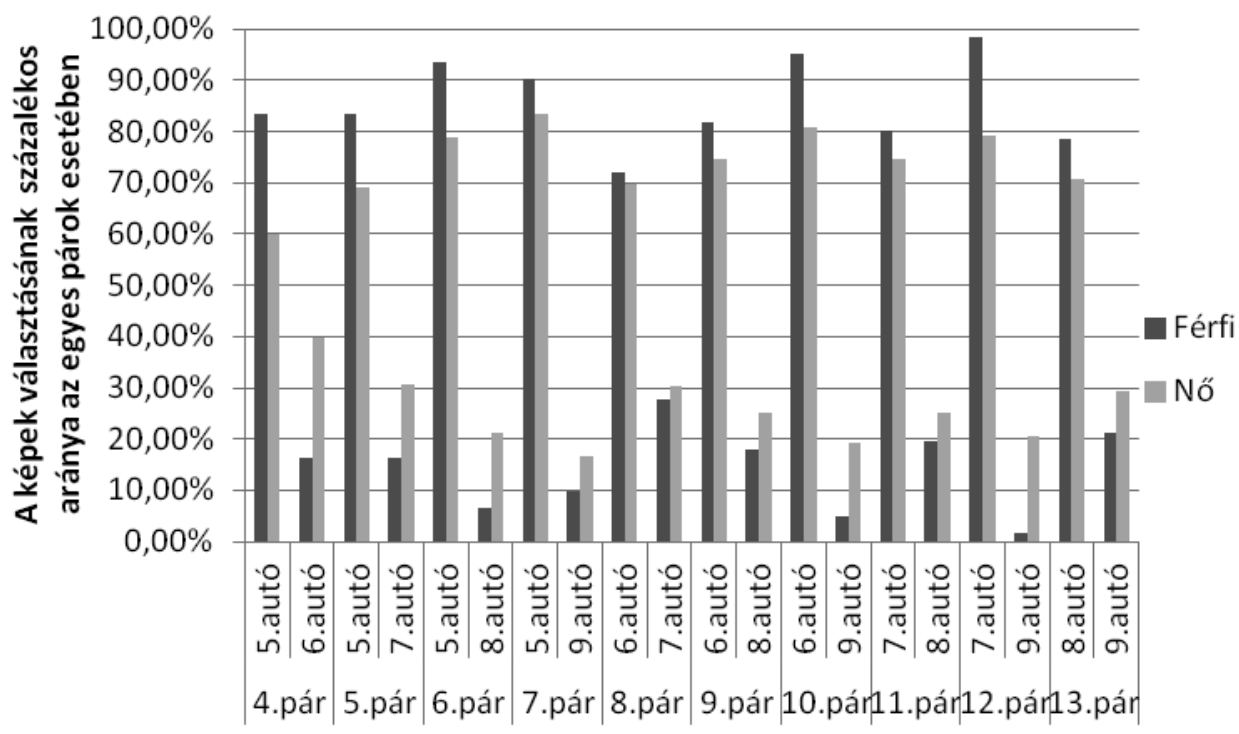

16. ábra. A finomabb különbségeket vizsgáló párok esetén az egyes képekre adott választások nemek szerinti eloszlása. A grafikonon a választások páronkénti százalékos eloszlását ábrázoltuk 
6. táblázat. Az inkább torzított autó választásának száma férfiak és nôk esetében (10-es pontérték: egyszer sem választották a nagyobb mértékben torzított képet, 20-as pontérték: mindig a torzítottabbat választották)

\begin{tabular}{|l|c|c|c|c|c|}
\cline { 2 - 6 } \multicolumn{1}{c|}{} & Nem & Elemszám & Átlag & Szórás & Az átlag hibája \\
\hline \multirow{2}{*}{ választások száma } & Férfi & 61 & 11,4262 & 2,04499 & 0,26183 \\
\cline { 2 - 6 } & Nố & 198 & 12,5859 & 2,85170 & 0,20266 \\
\hline
\end{tabular}

\section{DISZKUSSZIÓ}

\section{A kutatás fóbb eredményeinek megvitatása}

A jelen kutatás elsôsorban azzal a céllal indult, hogy megállapítsa, hogy a Lorenz által meghatározott babasémás jegyek pozitív irányba való torzítása az emberek aranyosságítéleteiben még magasabb értékeket vált-e ki, valamint hogy a manipulációban létezik-e egy optimális szint, amely után az értékelések negatív irányba mozdulnak el. A hatást olyan ingeranyag bevonásával sikerült igazolni, amely a séma természetes megjelenésétôl nagyban eltér. Ez az eredmények univerzalitását bizonyítja.

A vizsgálatunk kiindulópontját az a kutatás képezte, amely igazolta, hogy a babasémás jellegek akár az autók tervezése során is képesek éreztetni a hatásukat (Miesler és mtsai, 2011). A korábbi kutatással konzisztensen a mi minták esetében is egyértelmúen megfigyelhettük a séma erôteljes hatását, hiszen a vizsgálatunkban részt vevố személyek aranyosabbnak ítélték a babaarcok szerint torzított autókat. Képszerkesztô programok segítségével ezen túlmutatóan, lehetôség nyílt korábban nem tárgyalt feltételek bevezetésére is, így a babasémás jellegeket különbözô mértékben eltúlzó feltételek is megjelentek az ingeranyagban. Ahogyan arra elôzetesen számítottunk, a sémát pozitívabb irányba manipuláló képek esetében magasabb aranyosságértékeket kaptunk, ami alátámasztja, hogy a séma a természetes formájától eltérôen képes akár még erôteljesebb visszajelzések kiváltására is, tehát a szupernormális ingerekre jellemzó hatást mutat. Az egyre nagyobb mértékben megjelenô kihangsúlyozás azonban nem eredményezett egyenes arányú növekedést a személyek aranyosságészlelésében, hiszen egy bizonyos optimális szint után, az értékek - az elvárásunknak megfelelően - egyfajta csökkenést mutattak. Az optimum érdekes módon pont annál a manipulációnál volt megfigyelhetô, amely éppen kétszeresére növelte a vizsgálatunkban a babaarc arányait legjobban visszaadó kép jellemzôit. Ahhoz tehát, hogy az emberekból arcszerú mintázatokra, a lehetô legnagyobb mértékú reakciókat váltsunk ki aranyosság feladatokban, megközelítôleg 40\%-kal kell módosítanunk az eredeti képet a babaséma paraméterei mentén.

A különbözó képekre adott válaszokból nemcsak az optimumra, hanem a teljes folyamat hatására is következtetni tudunk. A képekre adott válaszok megoszlása az optimumon kívül az elsô kép lehetséges összehasonlításaiból állapítható meg a legjobban. Az eredeti képre adott ítéletek csak a második és az utolsó két képre adott válaszoktól nem térnek el, az összes többi autó pontértékénél azonban egyértelmúen alacsonyabb tendenciát mutatnak. Az eredményeket együtt szemlélve a manipulációnk hatása egy fordított U alakú haranggörbét rajzol ki, amelynek csúcsán a babaséma arányait körül- 
belül plusz 20\%-kal növelő, „optimális” eset áll, és amelynek két végén, bár látványra meglehetôsen különbözô képek állnak, a rájuk érkezett aranyosság ítéletek nem differenciálódnak.

A hatás univerzalitását igazolja, hogy az eredmények függetlenek voltak mind a személyek nemétől, mind a személyek lakóhelyétôl. Számos kutatás következtetéseivel egybehangzóan (Glocker és mtsai, 2009; Little, 2012; Luo és mtsai, 2011; Senese és mtsai, 2013) sikerült igazolni, hogy a babaszerû módosítás nemtôl függetlenül hat az aranyosságítéletekre. A jelen kutatás ezen túlmutatóan azt is bebizonyította, hogy a férfiak és a nôk hasonló tendenciával válaszolnak a babaarc jellegeit eltúlzó feltételek megjelenésére is. Az eredményekból ettől függetlenül nem lehet azt a következtetést levonni, hogy a babaséma hatása megegyezne a nemekre vonatkozólag, hiszen a szakirodalmi áttekintés alapján úgy látszik, hogy a nôk a babákkal való interakció során különbözô értékeket mutathatnak a férfiakkal szemben (Glocker és mtsai, 2009). A lakhellyel kapcsolatosan nem tudunk olyan kutatásról, amely ilyen jellegú csoportosítás szerint vizsgálta volna a résztvevôket. A kutatásban a hipotézisünknek megfeleló eredményt kaptunk, hiszen nem számítottunk arra, hogy a különbözô népességú településekrôl származó személyek válaszai egymástól jelentôs eltéréseket fognak mutatni. A séma az emberi szociális kogníció egyik alapköve, és a vizsgálat kimenetele egy újabb bizonyítékot szolgáltatott arra vonatkozóan, hogy a babaarcok hatása az emberi percepcióra evolúciós tôrôl fakad és az ingeranyag minôségétôl független.

Az aranyosabbnak ítélt babákat általában egyúttal egészségesebbnek, szerethetôbbnek és barátságosabbnak is látjuk (Little, 2012; Yamamoto és mtsai, 2009). A babásított arcok emellett orientálják a figyelmünket (Nittono és mtsai, 2012), tovább nézzük óket (Glocker és mtsai, 2009), ráadásul a férfiak sokkal inkább vonzódnak az ilyen arcberendezésú nôk iránt (Baudouin és Tiberghien, 2004). A korábbi vizsgálatok eredményeiból tehát egyértelmúen az látszik, hogy az aranyosság percepcióján túl magasabb preferencia- és kedvelésértékek is kapcsolódhatnak a babasémához. A kutatásunkban ezzel kapcsolatban a személyek autóválasztásai mögött megbújó tényezôket helyeztük a fókuszpontba. A vizsgálat kimenetele azt mutatja, hogy a nemek között bizonyos különbségek rajzolódnak ki, hiszen a nôk nagyobb arányban választották az erôsebb mértékben torzított autókat, a férfiakkal szemben. Ahogyan azt elôzetesen feltételeztük, a férfiak számára valamivel kevésbé vonzó tényezô az autó választásakor, hogy az autó megjelenése mennyire túnik aranyosnak. Az eredmények a babaséma hatásának egy újabb, korábban nem vizsgált nemi különbségét mutatták ki. Emellett azonban fontos megemlíteni, hogy bár a nemi különbségek statisztikailag is bebizonyosodtak, sem a férfiak, sem a nôk nem választották szívesebben az egyébként mindkét nem által aranyosabbnak ítélt autókat.

A nemi különbségek eltûnésére számítottunk abban az esetben, ahol a párosítások során az extrém mértékben eltorzított autó is megjelent. Ebben az esetben érdekes módon nem igazolódtak be az elốzetes jóslataink, hiszen a nók ebben a feladatrészben is nagyobb arányban választották, a babasémát háromszorosára torzított autót, mint a férfiak. Az eredmények megerôsítik a nemi különbségek meglétét az autóvásárlási preferenciában, de nem határoznak meg egy olyan extrém mértékú manipulációs értéket, amellyel kapcsolatosan a férfiak és a nôk egyöntetú aranyosságítélet-csökkenése látszik. Összességében elmondható, hogy az aranyosságészlelés és a vásárlási kedv disz- 
szociálódni látszik, hiszen az aranyosabbnak ítélt autók nem feltétlenül motiválják a személyeket arra, hogy az adott autót meg is vásárolják, hiszen mindkét nem esetében megjelent az a trend, miszerint a nagyobb mértékú torzítás csökkentette az adott autó választásának az esélyét.

\section{Kritikák, jövóbeli lehetôségek}

A kutatás során a csecsemóarc legfontosabb jellegzetességeit emeltük ki, tehát csak azokat, amelyek egy autó „arcára” is ráilleszthetôk anélkül, hogy természetellenes megjelenést kölcsönöznének a gépjármúnek. Ez azonban azzal járt, hogy bizonyos jellemzóket, mint például a pirospozsgás arc, az aránylag nagy fej vagy a gömbölyded arc, figyelmen kívül hagytuk annak ellenére, hogy feltehetôleg ezek a jellemzók is befolyásoló szereppel bírnak. Éppen ezért érdemes lenne megvizsgálni, hogy egyéb ingeranyag tekintetében, például babaarcok, felnôtt arcok, állati arcok vagy akár rajzfilmfigurák esetében hogyan alakul az aranyosságítéletek maximális szintje.

A vásárlási kedv esetén a vizsgálatunkban nem sikerült pontosan meghatározni, hogy melyik autó tekinthetô ebbốl a szempontból „optimális esetnek”, hiszen korlátozott képkészlettel dolgoztunk. Ha azonban a képpárok vizsgálatát az összes képre nézve elvégeznénk, akkor elképzelhetô, hogy ennél a feladatrésznél máshol rajzolódna ki az optimum, mint az aranyosságészlelési feladat során, sốt az is feltételezhetô, hogy a férfi-nôi optimumokban is mutatkoznának különbségek. Bár a vizsgálatunk során a vásárlási aranyosságítélet tekintetében nem sikerült igazolni a nemi különbségek eltûnését az extrém feltételre, a feltevésünket nem vetettük el. Meglátásunk szerint a jövôben érdemes lenne még szélsôségesebben kihangsúlyozni a babaséma jegyeit, egészen egy olyan állapotig, ahol a személyek választásaiban nemtôl függetlenül megjelenik a túlzott mértékú torzítás iránti ellenszenv.

A babaséma és az optimum összehasonlítása során érdemes lenne még megfigyelni, hogy az optimum a babasémához képest magasabb figyelemmegragadó hatással rendelkezik-e (Borgi és mtsai, 2014), megjelenik-e teljesítményjavulás bizonyos feladatokra nézve (Nittono és mtsai, 2012), illetve megállapíthatók-e aktívabban reagáló agyi területek (Glocker és mtsai, 2009). Ezekben a speciális kutatásokban szintén érdemes lenne megfigyelni a szélsôséges torzítások hatását.

A kutatásunk tanulságai arra engednek következtetni, hogy a jövôben célszerú lenne az aranyosságészlelési vizsgálatot páros összehasonlításokkal is elvégezni, hiszen ez amellett, hogy megerôsítené az optimumról alkotott elméletünket, kiküszöbölné a kísérletünk során megjelenô magas szórásértékeket. Úgy véljük, hogy az ilyen irányú kutatások nagyban gazdagítanák az optimumról alkotott ismereteket, és véglegesen bebizonyítanák, hogy a babasémát pozitív irányban torzított ingerre még erôteljesebb a várható reakció, amely után egy ponton egyfajta csökkenés következik be a válaszok erôsségében. Szintén további vizsgálódást igényel annak magyarázata, hogy vajon mi szab korlátot a preferencia folyamatos erôsödésének a babaséma változásának függvényében a 140\%-os torzítás után, hiszen erre a jelen vizsgálat adatai alapján nem következtethetünk, ezért érdemes lenne specifikusan is megvizsgálni a kérdést. 
A vizsgált minta a következtetések levonása szempontjából nem tekinthetố ideálisnak, hiszen a résztvevốk jelentôs része nô és a 18-tól 26-ig terjedô korosztályból kerül ki, így az eredmények nem általánosíthatóak a populációra vonatkoztatva, éppen ezért érdemes lenne a kutatást nagyobb és a népességre reprezentatív mintán megismételni. Emellett hasznos lenne a vizsgálatot kiegészíteni több, különféle autó bevonásával, hiszen a jelen kutatásban a vizsgálati személyek számára nem világos, hogy melyik megjelenô kép tekinthetô az alapállapotnak, így ez nem tekinthetô abszolút viszonyítási pontnak. Érdemes tehát több eredeti fotó bevonásával is megismételni a fenti eredményeket.

\section{Az optimum megállapításának alkalmazási lehetôségei}

A reklámiparban így régóta bevett és elterjedt szokás a babasémák használata, hiszen az aranyosabbnak ítélt figurákat általában jobban is kedveljük, az általunk megállapított „optimális eset” pedig ezeket a hatásokat a lehetô legnagyobb mértékben tudná érvényre juttatni. A gondolatot kibôvítve bármilyen területen (pl. filmipar, szórakoztatóipar, játékipar), ahol mesterséges karakterek kialakításával szeretnék a megfigyelôk aranyosságítéletét nagymértékben befolyásolni, az általunk meghatározott arányok alkalmazásával érhetô el a legerôteljesebb hatás.

Az autógyártás során szintén felhasználhatók a vizsgálat során kimutatott eredményeink. Az adatokat a választások gyakoriságára vonatkozóan szemlélve azt állapíthatjuk meg, hogy az autó arculatának tervezése során nem megfelelô stratégia kihangsúlyozni a babaarcra jellemzó jegyeket, hiszen a teljes mintára vonatkoztatva a résztvevốk ritkábban választották a nagyobb mértékben torzított autókat az alacsonyabb mértékben torzítottakhoz képest. Ettől függetlenül az adatok alapján megállapítható, hogy a nôkre, a férfiakkal összehasonlítva, valamivel erôteljesebb hatással van, ha az autó aranyos benyomást kelt.

\section{Konklúzió}

Összefoglalásképpen elmondhatjuk, hogy az autók arcának különbözô mértékú manipulálásával, sikerült demonstrálnunk, hogy a babaséma, amely evolúciós szempontból az utód túlélésének egyik legmeghatározóbb tényezôje, nem a természetes megjelenésével váltja ki a legerôteljesebb hatást az emberek aranyosságészlelésére, hanem a babaarc jellegeinek egy megnövelt változatában. A kutatás során felfedeztünk egy korábban nem ismert különbséget is a nemek között a vásárlási preferenciák tekintetében, amely az eredményeink alkalmazási lehetôségeinek kibóvítésére hívja fel a figyelmet. Emellett egy új perspektívából sikerült igazolnunk a babaséma és az optimum általános megjelenését és egyedülálló szerepét a humán percepcióban. A vizsgálatunk által megállapított „optimum” tehát egy új fejezetet nyithat a babaséma tanulmányozásának széles körú irodalmában, hiszen számos új kutatási irányvonalat képezhet, amely a séma kulcsfontosságú funkcióján túl a csecsemô-gondozó interakcióban megannyi más területen elôidézett hatásra is rávilágíthat. 


\section{KÖSZÖNETNYILVÁNÍTÁS}

A cikk elkészüléséért szeretnék köszönetet mondani dr. Kovács Ilona tanárnônek a kutatás során nyújtott támogatásáért és iránymutatásáért, valamint Soltész-Várhelyi Klárának és Novák Bálintnak a statisztikai elemzésekkel kapcsolatos segítségükért.

\section{IRODALOM}

Agthe, M., Spörrle, M., \& Maner, J. K. (2011). Does being attractive always help? Positive and negative effects of attractiveness on social decision making. Personality and Social Psychology Bulletin, 37(8), 1042-1054. doi:10.1177/0146167211410355

Baudouin, J.-Y., \& Tiberghien, G. (2004). Symmetry, averageness, and feature size in the facial attractiveness of women. Acta Psychologica, 117(3), 313-32. doi:10.1016/j.actpsy.2004.07.002

Borgi, M., Cogliati-Dezza, I., Brelsford, V., Meints, K., \& Cirulli, F. (2014). Baby schema in human and animal faces induces cuteness perception and gaze allocation in children. Frontiers in Psychology, 5(May), 1-12. doi:10.3389/fpsyg.2014.00411

Glocker, M. L., Langleben, D. D., Ruparel, K., Loughead, J. W., Gur, R. C., \& Sachser, N. (2009). Baby Schema in Infant Faces Induces Cuteness Perception and Motivation for Caretaking in Adults. Ethology, 115(3), 257-263. doi:10.1111/j.1439-0310.2008.01603.x

Glocker, M. L., Langleben, D. D., Ruparel, K., Loughead, J. W., Valdez, J. N., Griffin, M. D. et al. (2009). Baby schema modulates the brain reward system in nulliparous women. PNAS, 106(22), 9115-9119.

Jacob, J. E., Rodenhauser, P., \& Markert, R. J. (1986). The Benign Exploitation of Human Emotions : Adult Women and the Marketing of Cabbage Patch Kids. Journal of American Culture, 10(3), 61-71.

Lábadi, B. (2011). A lábujjától a feje búbjáig. A testreprezentációról. In Deák A., Nagy L., \& Péley B. (szerk.), Lélek-Képek (pp. 119-131). Pécs: Pannónia Könyvek.

Little, A. C. (2012). Manipulation of Infant-Like Traits Affects Perceived Cuteness of Infant, Adult and Cat Faces. Ethology, 118(8), 775-782. doi:10.1111/j.1439-0310.2012.02068.x

Lorenz, K. (1943). Die angeborenen Formen moeglicher Erfahrung. Tierpsychol, 5, 235-409.

Luo, L. Z., Li, H., \& Lee, K. (2011). Are children's faces really more appealing than those of adults? Testing the baby schema hypothesis beyond infancy. Journal of Experimental Child Psychology, 110(1), 115-24. doi:10.1016/j.jecp.2011.04.002

Meskó, N. (2010). Női arc és hajviselet: a saját szépséggel összefüggő alternatív párválasztási taktika. Magyar Pszichológiai Szemle, 65(1), 133-147. doi:10.1556/MPSzle.65.2010.1.10

Miesler, L., Leder, H., \& Herrmann, A. (2011). Isn't it cute: An Evolutionary Perspective of Baby-Schema Effects in Visual Product Designs. International Journal of Design, 5(3), 17-30.

Nittono, H., Fukushima, M., Yano, A., \& Moriya, H. (2012). The Power of Kawaii: Viewing Cute Images Promotes a Careful Behavior and Narrows Attentional Focus. PLoS ONE, 7(9), 1-7. doi:10.1371/journal.pone.0046362

Parsons, C. E., Young, K. S., Kumari, N., Stein, A., \& Kringelbach, M. L. (2011). The motivational salience of infant faces is similar for men and women. PLoS ONE, 6(5), 2-6. doi:10.1371/ journal.pone.0020632

Rossiter, J., Langner, T., \& Ang, L. (2003). Visual creativity in advertising: a functional typology In R. Kennedy (Ed.), Proceedings of the Australian and New Zealand Marketing Academy Conference (pp. 105-113). Adelaide: Australian and New Zealand Marketing Academy. Retrieved from http://ro.uow.edu.au/commpapers/2877/ 
Staddon, J. E. . (1975). A note on the evolutionary significance of "supernormal" stimuli. American Naturalist, 109(969), 541-545.

Yamamoto, R., Ariely, D., Chi, W., Langleben, D. D., \& Elman, I. (2009). Gender differences in the motivational processing of babies are determined by their facial attractiveness. PloS One, 4(6), e6042. doi:10.1371/journal.pone.0006042 


\section{MELLÉKLETEK}

\section{A kérdôív kitöltése után megjelenô ismertetô a kutatásról}

„Konrad Lorenz vetette fel elôször, hogy a baba arcának bizonyos fizikai jellemzői, mint a nagy fej, a gömbölyded arc, a magas homlok, a kis orr és száj valamint a nagy szem - amelyek a kisbabák arcának jellemzôi - vonzónak, aranyosnak hatnak, és gondozóviselkedésre irányuló motivációt aktiválnak a felnốttekben. A séma azonban nem csak ebben a szúk értelemben nyer jelentôséget, a preferencia ennél sokkal általánosabban is jelen van, hiszen a gondozástól független helyzetekben is megfigyelhetố a hatása. A babák arcának sémáit így számos területen felhasználják, például a reklámés a játékiparban, kimutatható, hogy sokkal pozitívabban viszonyulunk a babaséma alapján bemutatott arcokra, figurákra. A populáris kultúrában tehát komoly jelentôséget tulajdonítanak neki, többek között ez lehet az oka Mickey Mouse és Garfield töretlen sikerének, de számos egyéb helyzetben is megfigyelhetjük hatását. Korábbi kutatások megmutatták, hogy a séma legfőbb jegyei akár autók esetén is befolyásolják észlelésünket. Ebben a megközelítésben a kocsi fényszórói egy szemre, az autó rácsozása egy emberi orra, míg a szellôzoonyílás szájra emlékeztetnek. A kutatás arra helyezi a legnagyobb hangsúlyt, hogy a séma erôteljes, eltúlzott megjelenései milyen kedvelés értékeket váltanak ki a vizsgálati személyekben. Az elsôdleges célom, hogy meghatározzam ennek a túlzásnak az optimális szintjét, amely esetében az emberek a legnagyobb aranyosságértékeket mutatják. A vizsgálatban való részvételét és segítségét köszönöm!”

\section{Az 1.(eredeti), az 5.(babasémaszerú), a 9.(feltételezett optimum) és a 13.(extrém) kép kontrasztvizsgálatai}

\begin{tabular}{|l|l|c|c|c|c|c|}
\hline \multirow{2}{*}{$\begin{array}{l}\text { Az egyes } \\
\text { képek } \\
\text { kontraszt- } \\
\text { vizsgálatai }\end{array}$} & \begin{tabular}{l} 
kz összehasonlított \\
\cline { 2 - 7 }
\end{tabular} & $\begin{array}{c}\text { Szabadság- } \\
\text { fokok }\end{array}$ & $\begin{array}{c}\text { Átlag- } \\
\text { négyzet }\end{array}$ & F-érték & Szignifikancia & $\begin{array}{c}\text { Parciális } \\
\text { eta-négyzet }\end{array}$ \\
\cline { 2 - 7 } & 5. kép vs. 9. kép & 1 & 50,178 & 24,904 & 0,000 & 0,088 \\
\cline { 2 - 7 } & 9. kép vs. 13. kép & 1 & 102,583 & 24,818 & 0,000 & 0,063 \\
\hline
\end{tabular}


III. Az elsố három pár Pearson-féle $\chi^{2}$ tesztje

\begin{tabular}{|l|c|c|c|c|c|}
\hline & $\mathrm{N}$ & Érték & Szabadságfok & $\begin{array}{c}\text { Kétoldali } \\
\text { szignifikancia }\end{array}$ & $\varphi$ \\
\hline Az 1. pár khi négyzet tesztje & 163 & 6,815 & 1 & 0,009 & 0,162 \\
\hline A 2. pár khi négyzet tesztje & 237 & 7,407 & 1 & 0,006 & 0,169 \\
\hline A 3. pár Fisher Exact tesztje & 259 & 7,041 & 1 & 0,005 & 0,165 \\
\hline
\end{tabular}

IV. A független mintás t-próba eredménye a finomabb különbségeket vizsgáló párok esetében

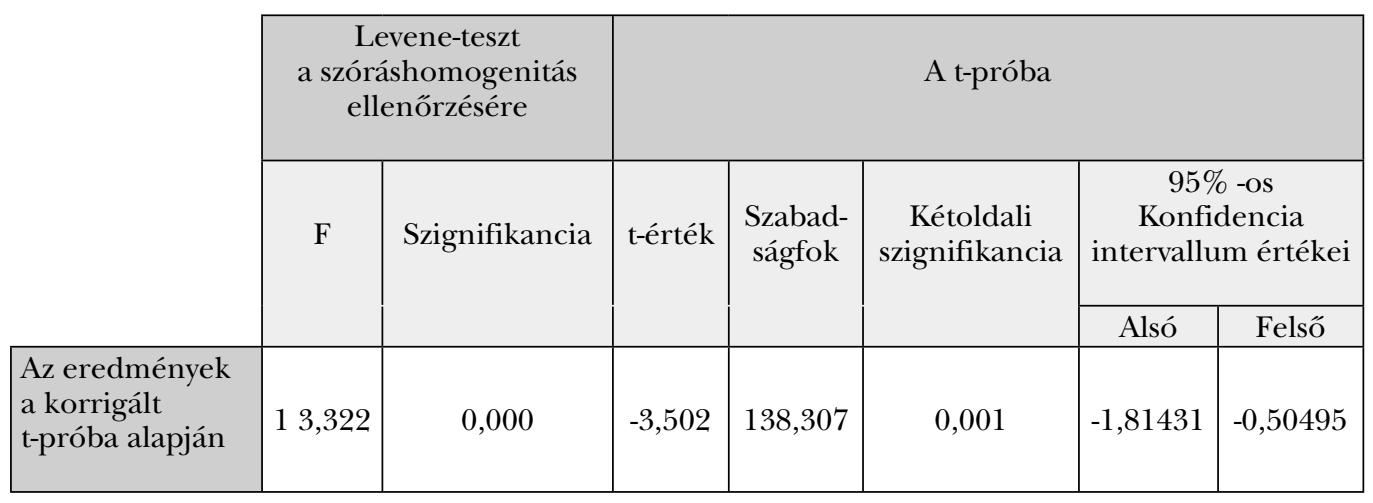




\title{
EXAMINING THE OPTIMAL LEVEL OF THE BABY SCHEMA ON LIFELESS OBJECTS
}

\begin{abstract}
KISS-LEIZER, MÁRTON
Ethologist Konrad Lorenz was the first to describe the concept of "baby schema" as a set of facial characteristics of infants, such as a large head, round face, small nose and large eyes. Adults perceive these features as cute, which has evolutional importance in motivating individuals for care taking behaviour and in turn increasing the offspring's chances of survival. Previous work on this fundamental concept also suggests a strong effect of the schema on human perception of lifeless objects. In this study, we experimentally tested the effects of baby schema on perception of extent of "cuteness", using frontal photographs of cars, representing the vehicles' "faces". Employing graphic and image editor techniques, we manipulated the baby schema content by changing the characteristics of car "faces". We created 13 pictures that contained the features of the baby schema attributions to different degrees (from 0\% to 60\%) and we expected that there would be a preferred level of these features, with maximal "cuteness" ratings by participants. The results showed that around the picture manipulated to double of the original size was rated as the cutest from all of the images, while there were no differences between the ratings of the original picture and the one manipulated to triple the original parameters. It can be concluded that the extreme manipulation made the cuteness ratings lower, while a particular degree of application of the baby schema made ratings of cuteness the highest.

Our findings indicate that when assessing people's ratings of cuteness, there is an optimal level in the extent to which an image should manipulated to match the baby schema, to result in the "cutest" image.

Due to their generalisability to other lifeless objects, the results can be applied widely to the film or advertising industries.
\end{abstract}

Key words: baby schema, optimal level, car faces, supernormal stimuli 